\title{
Efficiency of solid waste collection in Spain
}

\author{
I. M. García Sánchez \\ Department of Administration and Business, \\ University of Salamanca, Spain
}

\begin{abstract}
One of the major environmental problems for society is the great quantity of solid waste generated. The management of urban solid waste is one of the most important services and for this reason town councils have to maintain the cities in the proper hygienic and aesthetic conditions for their inhabitants as well as for tourists or visitors.

The loss of credibility of the Spanish municipal public sector as a manager of this service is accompanied by manifestations demanding and forcing the sector to act by applying the principle of efficiency. These new demands require the development and application of control techniques that provide relevant information for decision-making.

In the present work we examine the waste collection scheme in Spain using the Data Envelopment Analysis (DEA) methodology in terms of calculation of the efficiency, showing the vast information that may be provide by this technique.

The results of this study showed that the average technical efficiency of waste collection is situated at $56.94 \%$. Out of the 34 towns examined, the $73.53 \%$ were found inefficient. The analysis of slacks reveals a resource excess of about $9 \%$ above the optimal collection activity.

Keywords: data envelopment analysis, solid waste collection, public sector, municipalities.
\end{abstract}

\section{Introduction}

One of the major environmental problems for society is the great quantity of solid waste generated. The management of urban solid waste is one of the most important services and for this reason town councils have to maintain the cities 
in the proper hygienic and aesthetic conditions for their inhabitants as well as for tourists or visitors.

The loss of credibility of the Spanish municipal public sector as a manager of this service is accompanied by manifestations demanding and forcing the sector to act by applying the principle of efficiency. These new demands require the development and application of control techniques that provide relevant information for decision-making about the relation between the quantity of resources used in the production and development of the appropriate quantity and quality of goods or services in a suitable time. Owing to the scarce significance of the value of the public output, its measurement is defined as the estimation of technical efficiency by inputs and outputs expressed in physical terms.

The present work focuses on the study of the efficiency of urban solid waste collection. Hence, the technical efficiency of the service is calculated with the aim of detecting potential savings in the use of physical resources, which lead to an increase in productivity.

According with the evidence of the large number of studies carried out in various countries - e.g. Portugal [3], the United Kingdom [4], Australia [7], France [2], Switzerland [1], Finland [5] and America [6]- Data Envelopment Analysis (DEA) was utilized to estimate the efficiency.

\section{Data Envelopment Analysis}

DEA yields a piecewise linear production surface that, in economic terms represents the best practice production frontier. By projecting each unit onto the frontier, it is possible to determine the level of inefficiency by comparison to a single reference unit or a convex combination of other reference units. The projection refers to a hypothetical DMU which is a convex combination of one or more efficient DMUs and not an actual DMU.

The basic DEA model, named CCR is expressed as follows (1):

Given a set of $\mathrm{J}$ DMUs, the model determines for each $\mathrm{DMU}_{0}$ the optimal set of input weights and output weights that maximizes its efficiency score $\delta_{0}$. A score less than one means that a linear combination of other units from the sample could produce the vector of outputs using a smaller vector of inputs. Mathematically, a DMU is termed efficient if its efficiency rating $\delta_{0}$ obtained from the DEA model is equal to one. Otherwise, the DMU is considered inefficient.

\section{Aims and selection of variables}

\subsection{Sample}

In order to estimate the efficiency, the population selected comprised the 113 towns of over 50,000 inhabitants that exist in Spain in 1999. Specifically, we obtained information from 34 towns that make up $30.09 \%$ of the population. The 
technique used for obtaining information was the questionnaire, which, forwarded to the population, guarantees randomness in the data obtained.

\subsection{Inputs and outputs}

In this section the indicators that represent the functions of this service will be selected, grouped in indicators of input and output.

\subsubsection{Inputs}

The production process of municipal solid waste collection is highly contingent upon the supply of capital and human resources. The latter is represented, in general, by total staff and our analysis will include the indicator expressed in terms of total workers. In relation to the capital goods, the basic element is the vehicles measured in physical units.

\subsubsection{Outputs}

The variables tonnage (Output1) and collection points (Output2) correspond to the most used indicators for identifying the final product of the activity of waste collection. They represent the volume of solid waste generated and the number of places where it is collected, respectively.

\section{Empirical analysis}

\subsection{Efficiency index}

In this stage, we estimate the technical inefficiencies of the Spanish towns for solid waste collection and street cleaning. The results are given in table 1 .

According to the results, of the 34 units examined 25 are inefficient, that is, approximately $73.5 \%$ of the total of local authorities evaluated. Only nine towns were considered efficient: Guadalajara, Barcelona, Castellón, Hospitalet, Bilbao, Mieres, Ciudad Real, Tenerife and Madrid.

The technical inefficiency measured is situated at $56.94 \%$, there being a significant slack of potential improvement, which is expressed in a possible average reduction of the inputs of around $9 \%$. The greatest slack, figure 1 , is basically correlated with the variable tonnage, collection points being carried out more optimally.

\subsection{Best-practice in solid waste collection and inefficient units}

DEA displays performance information relating to inefficient towns and shows the difference between their performance and the "best practice" $(100 \%$ efficient) municipalities to which they have been compared.

Potential improvements indicate by how much and in what areas an inefficient town needs to improve in order to be efficient. For example, Figure 2 shows what percentage Salamanca needs to either decrease its inputs or increase its outputs in order to become $100 \%$ efficient: it needs to reduce its number of 
staff by nearly $40 \%$ or its vehicles around $7 \%$, while maintaining the same level of outputs.

Table 1: $\quad$ Technical Efficiency Index.

\begin{tabular}{|c|c|c|c|}
\hline MUNICIPALITIES & $\begin{array}{l}\text { Technical } \\
\text { Efficiency } \\
\text { Index }\end{array}$ & MUNICIPALITIES & $\begin{array}{l}\text { Technical } \\
\text { Efficiency } \\
\text { Index }\end{array}$ \\
\hline GUADALAJARA & 100 & SEVILLA & 38.60 \\
\hline BARCELONA & 100 & TORREJON & 36.62 \\
\hline CASTELLON & 100 & MANRESA & 35.29 \\
\hline HOSPITALET & 100 & MALAGA & 35.12 \\
\hline BILBAO & 100 & OVIEDO & 32.21 \\
\hline CIUDAD REAL & 100 & SANTA COLOMA & 31.30 \\
\hline MIERES & 100 & FUENLABRADA & 29.36 \\
\hline TENERIFE & 100 & VITORIA & 29.34 \\
\hline MADRID & 100 & EL FERROL & 27.60 \\
\hline SALAMANCA & 92.14 & SAGUNTO & 27.17 \\
\hline LLEIDA & 84.33 & LORCA & 23.99 \\
\hline GRANADA & 80.95 & MELILLA & 22.22 \\
\hline GIJÓN & 70.49 & CORDOBA & 21.37 \\
\hline PAMPLONA & 67.74 & $\begin{array}{l}\text { ALCALA } \\
\text { GUADAI }\end{array}$ & 19.73 \\
\hline A CORUÑA & 48.12 & ALGECIRAS & 12.34 \\
\hline $\begin{array}{l}\text { PALMA } \\
\text { MALLOR }\end{array}$ & 45.16 & & \\
\hline MARBELLA & 42.81 & $\begin{array}{l}\text { AVERAGE } \\
\text { EFFICIENCY }\end{array}$ & 56.94 \\
\hline VILANOVA & 42.76 & $\begin{array}{l}\text { EFFICIENCT } \\
\text { UNITS }\end{array}$ & $9(26.47 \%)$ \\
\hline VALENCIA & 39.04 & $\begin{array}{l}\text { INEFFICIENT } \\
\text { UNITS }\end{array}$ & $25(73.53 \%)$ \\
\hline
\end{tabular}

If the assessment of a town as inefficient is felt to be justified then the information provided can be used as a basis for setting targets for the municipality. As a first step insetting targets, the inefficient unit should be compared with the towns in its reference set.

The reference set is the set of efficient municipalities to which the unit has been most directly compared when calculating its efficiency rating, table 2 . Salamanca has efficient towns Barcelona, Ciudad Real and Tenerife.

However the reference set towns do not all contribute equally to the targetvalues for an inefficient municipality. Some reference set town are more important than others. Figure 3 shows all the towns in Salamanca's reference set and how much in percentage terms they have each contributed to forming the target values for each of Salamanca's inputs and outputs. 

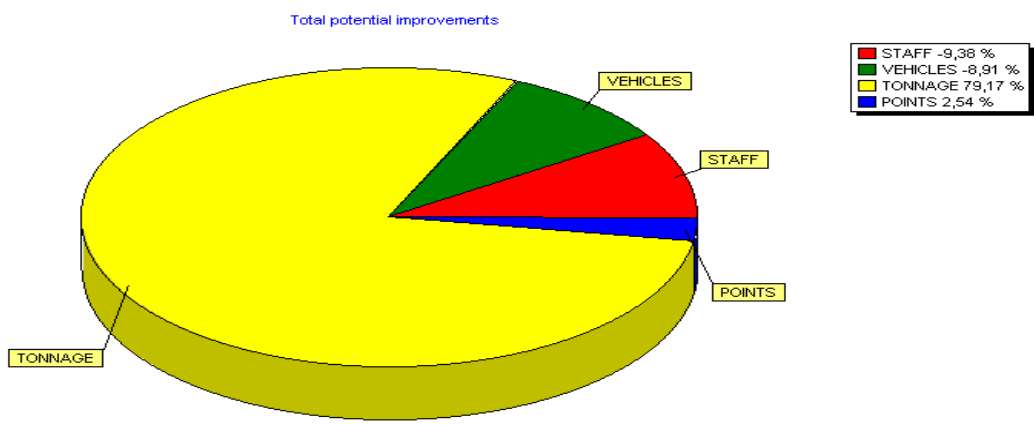

Figure 1: $\quad$ Potential average savings and increases.

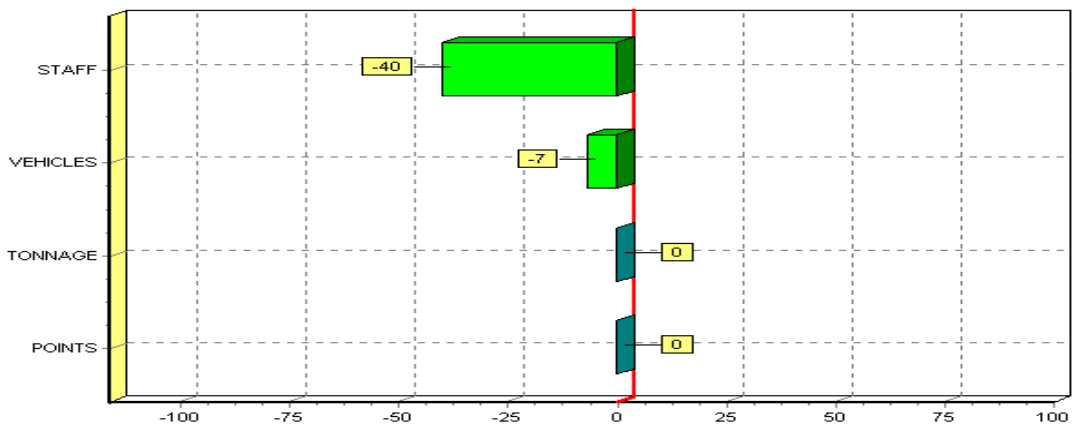

Figure 2: Salamanca: potential improvements.

Table 2: $\quad$ Group of references.

\begin{tabular}{|c|c|c|c|c|c|c|c|c|c|}
\hline & \multicolumn{9}{|c|}{ EFFICIENT MUNICIPALITIES } \\
\hline $\begin{array}{c}\text { INEFFICIENT } \\
\text { MUNICIPALITIES }\end{array}$ & Guadalajara & Barcelona & Hospitalet & Castellon & $\begin{array}{c}\text { Bilbao } \\
\end{array}$ & Ciudad Real & Mieres & Tenerife & Madrid \\
\hline $\begin{array}{l}\text { SALAMANCA } \\
\end{array}$ & & $\mathrm{X}$ & & & & $\mathrm{X}$ & & $\mathrm{X}$ & \\
\hline LLEIDA & $\mathrm{X}$ & & $\mathrm{X}$ & $\mathrm{X}$ & $\mathrm{X}$ & & & & \\
\hline GRANADA & $\mathrm{X}$ & $\mathrm{X}$ & & & & $\mathrm{X}$ & & $\mathrm{X}$ & \\
\hline GIJÓN & & $\mathrm{X}$ & & & & $\mathrm{X}$ & & & \\
\hline PAMPLONA & & $\mathrm{X}$ & $\mathrm{X}$ & $\mathrm{X}$ & $\mathrm{X}$ & & & & \\
\hline A CORUÑA & & $\mathrm{X}$ & & $\mathrm{X}$ & & $\mathrm{X}$ & & $\mathrm{X}$ & \\
\hline PALMA DE MALLOR & $\mathrm{X}$ & $\mathrm{X}$ & $\mathrm{X}$ & $\mathrm{X}$ & $\mathrm{X}$ & & & & \\
\hline MARBELLA & & $\mathrm{X}$ & $\mathrm{X}$ & & & & & & \\
\hline VILANOVA & & & & $\mathrm{X}$ & & & $\mathrm{X}$ & $\mathrm{X}$ & \\
\hline VALENCIA & & & & & & & & $\mathrm{X}$ & $\mathrm{x}$ \\
\hline SEVILLA & $\mathrm{X}$ & $\mathrm{X}$ & & & & $\mathrm{X}$ & & $\mathrm{X}$ & \\
\hline TORREJON & $\mathrm{X}$ & & & $\mathrm{X}$ & & $\mathrm{X}$ & $\mathrm{X}$ & & \\
\hline MANRESA & $\mathrm{X}$ & & & & $\mathrm{X}$ & & $\mathrm{X}$ & & \\
\hline MALAGA & & & & & & & $\mathrm{X}$ & & \\
\hline OVIEDO & $\mathrm{X}$ & $\mathrm{x}$ & $\mathrm{X}$ & $\mathrm{X}$ & $\mathrm{X}$ & & & & \\
\hline SANTA COLOMA & $\mathrm{X}$ & $\mathrm{X}$ & $\mathrm{X}$ & & & & & & \\
\hline FUENLABRADA & $\mathrm{X}$ & $\mathrm{X}$ & $\mathrm{X}$ & & & & & & \\
\hline VITORIA & $\mathrm{X}$ & & $\mathrm{X}$ & & $\mathrm{X}$ & & & & \\
\hline EL FERROL & $\mathrm{X}$ & & & $\mathrm{X}$ & & $\mathrm{X}$ & $\mathrm{X}$ & & \\
\hline SAGUNTO & $\mathrm{X}$ & & & & $\mathrm{X}$ & & $\mathrm{X}$ & & \\
\hline LORCA & $\mathrm{X}$ & & & & $\mathrm{X}$ & & $\mathrm{X}$ & & \\
\hline MELILLA & $\mathrm{X}$ & & & & & & & & \\
\hline CORDOBA & & $\mathrm{X}$ & $\mathrm{X}$ & $\mathrm{X}$ & $\mathrm{X}$ & & & & \\
\hline $\begin{array}{l}\text { ALCALA DE GUADAI } \\
\text { ALGECIRAS }\end{array}$ & $\mathrm{X}$ & $\begin{array}{l}\mathrm{X} \\
\mathrm{X}\end{array}$ & $\mathrm{X}$ & $\mathrm{X}$ & & & & & \\
\hline FREQUENCY & 15 & 14 & 10 & 10 & 9 & 7 & 7 & 6 & 1 \\
\hline Percentage & $60 \%$ & $56 \%$ & $40 \%$ & $40 \%$ & $36 \%$ & $28 \%$ & $28 \%$ & $24 \%$ & $4 \%$ \\
\hline
\end{tabular}




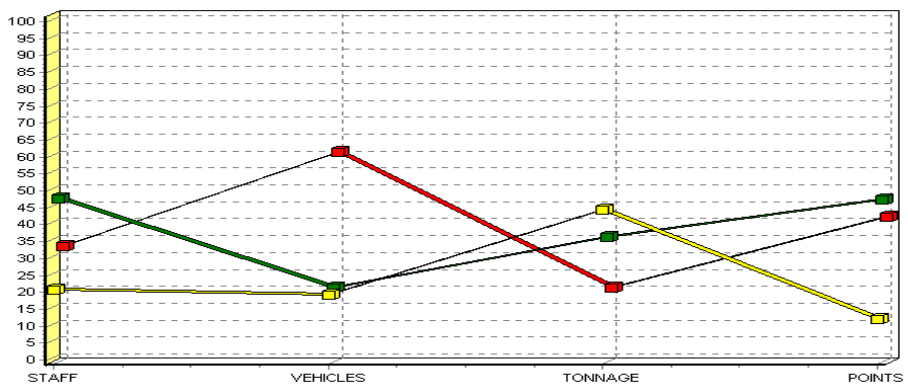

Figure 3: Salamanca: reference contributions.

\section{Conclusions}

A methodology of evaluation of the efficiency of waste collection has been established in this work. It provides not only an efficiency score for each town but also indicates by how much and what areas an inefficient municipality needs to improve in order to be inefficient. As regards the results reveals that:

- $\quad$ Of the 34 towns examined, 25 are inefficient, $73.53 \%$.

- $\quad$ The average technical efficiency is relatively short, 56.94 .

- The analysis of slacks reveals surplus resources of around 9\%.

- The collection activity being carried out more optimally.

$$
\operatorname{Max} \delta_{\mathrm{o}}=\frac{\sum_{\mathrm{i}} u_{\mathrm{i}} \mathrm{y}_{\mathrm{io}}}{\sum_{\mathrm{j}} v_{\mathrm{j}} \mathrm{x}_{\mathrm{jo}}}
$$

Subject to:

$$
\begin{array}{cl}
\frac{\sum_{\mathrm{i}} u_{\mathrm{i}} \mathrm{y}_{\mathrm{ik}}}{\sum_{\mathrm{j}} v_{\mathrm{j}} \mathrm{x}_{\mathrm{jk}}} \leq 1 \quad & \text { for all DMUs } \mathrm{K}=1, \ldots, \mathrm{n} \\
& u_{\mathrm{i},} v_{\mathrm{j}} \geq \mathrm{o}
\end{array}
$$

where,

$\delta_{0}=$ the efficiency score of the DMU 0 under analysis; $n=$ number of DMUs under analysis;

$\mathrm{i}=$ number of outputs; $\mathrm{j}=$ number of inputs;

$Y_{k}=\left(\mathrm{y}_{1 \mathrm{k}}, \mathrm{y}_{2 \mathrm{k}}, \ldots, \mathrm{y}_{\mathrm{ik}}, \ldots, \mathrm{y}_{\mathrm{Ik}}\right)$ is the vector of outputs for DMU $\mathrm{k}$ with $\mathrm{y}_{\mathrm{ik}}$ being the value of output i for DMU $\mathrm{k}$;

$X_{k}=\left(\mathrm{x}_{1 \mathrm{k}}, \mathrm{x}_{2 \mathrm{k}}, \ldots, \mathrm{x}_{\mathrm{jk}}, \ldots, \mathrm{y}_{\mathrm{Ik}}\right)$ is the vector of inputs for DMU $\mathrm{k}$ with $\mathrm{x}_{\mathrm{ik}}$ being the value of input $\mathrm{j}$ for DMU $\mathrm{k}$;

$\mu$ and $v$ the vector on multipliers respectively set on $\mathrm{Y}_{\mathrm{k}}$ and $\mathrm{X}_{\mathrm{k}}$ where $\mu_{i}, v_{j}=$ the respective weights for output $\mathrm{i}$ and for input $\mathrm{j}$; 


\section{References}

[1] Burgat, P. and Jeanrenaud, C., Measure de l'efficacité productive, Working Paper IRER, Universitat de Neuchatel, 1990.

[2] Distexhe, V., .L'Efficacité Productive des Services D'Enlévement des Immondices en Wallonie. Cahiers Economiques de Bruxelles 137, p.p. 119-138, 1993.

[3] Gaiola, A.J.F., Efficiency Evaluation in the Urban Solid Waste Systems of Portugal Using Data Envelopment Analysis, Symposium at a Glance, Moscow, 2002.

[4] Haas, D.A., Murphy, F.H., and Lancioni, R.A., Managing Reverse Logistics Channels with Data Envelopment Analysis. Transportation Journal 42(3), p.p. 105-113, 2003.

[5] Jenkins, L. and Anderson, M., A Multivariate Statistical Approach to Reducing the Number Variables in Data Envelopment Analysis. European Journal of Operational Research 147, p.p. 51-61, 2003.

[6] Segal, G.F., Moore, A.T. and Nolan, J., California Competitive Cities: A Report Card on Efficiency in Service Delivery in California's Largest Cities, Reason Public Policy Institute, California, 2002.

[7] Whortington, A.C. and Dollery, B.E., Measuring Efficiency in Local Government: An Analysis of New South Wales Municipalities Domestic Waste Management Function. Policy Studies Journal 29(2), p.p. 4-24, 2001 . 